\title{
Crystallization and Structural Determination of the Receptor-Binding Domain of MERS-CoV Spike Glycoprotein
}

\author{
Haixia Zhou, Shuyuan Zhang, and Xinquan Wang
}

\begin{abstract}
Three-dimensional structures of the receptor-binding domain (RBD) of MERS-CoV spike glycoprotein bound to cellular receptor and monoclonal antibodies (mAbs) have been determined by X-ray crystallography, providing structural information about receptor recognition and neutralizing mechanisms of mAbs at the atomic level. In this chapter, we describe the purification, crystallization, and structure determination of the MERS-CoV RBD.
\end{abstract}

Key words X-ray crystallography, MERS-CoV, Spike, RBD, Crystallization, Structure determination

1 Introduction

The first three-dimensional structure of the MERS-CoV spike glycoprotein receptor-binding domain (RBD), providing the molecular basis of viral attachment to host cells, was determined in the complex with it cellular receptor dipeptidyl peptidase 4 (DPP4, also called CD26) by X-ray crystallography [1]. Because of the significance in receptor recognition and specific pathogenesis, RBD became a hot spot in the study of MERS-CoV. A number of structures of RBD bound by monoclonal antibodies (mAbs) have also been determined and deposited in the Protein Data Bank (PDB, http://www.rcsb.org/pdb/) [2-8]. Our group determined the RBD structures in complex with DPP4 and the mAbs MERS27, MERS-4 and MERS-GD27, respectively [2-4, 9]. All the three-dimensional structures of MERS-CoV RBD have been determined by X-ray crystallography, which is a powerful method for determining molecular structures at atomic resolution. Briefly, the ordered and repeated atoms in a single protein crystal can diffract the incident X-ray beam into many specific directions. The angles and intensities of these diffracted X-rays can be collected and 
measured in an X-ray diffraction experiment. After obtaining the phases of these diffracted X-rays by heavy-atom derivative, anomalous scattering or molecular replacement methods, a protein crystallographer then calculates the density of electrons with the protein crystal and builds a structural model based on the density map. For details on the principles and methodology of protein crystallography, please refer to the range of other excellent textbooks.

In this chapter, an overview of the standard method of protein crystallography is briefly introduced, focusing on crystallization and structural determination of MERS-CoV RBD using the molecular replacement method.

\section{Materials}

\subsection{Expression}

\subsection{Purification}

Prepare all solutions using ultrapure water (prepared by purifying deionized water, to attain a resistivity of $18 \mathrm{M} \Omega \mathrm{cm}$ at $25^{\circ} \mathrm{C}$ ) and analytical grade reagents. When dealing with waste, we strictly follow all waste disposal regulations.

1. pFastBac vector containing the MERS-CoV RBD gene.

2. DHl0Bac competent cells.

3. LB liquid medium: $10 \mathrm{~g}$ tryptone, 5 g yeast extract, $10 \mathrm{~g} \mathrm{NaCl}$, and $1 \mathrm{~L}$ ultrapure water; sterilize by high-pressure steam.

4. Liquid LB selection medium: LB liquid medium, $50 \mu \mathrm{g} / \mathrm{mL}$ kanamycin, $7 \mu \mathrm{g} / \mathrm{mL}$ gentamicin, and $10 \mu \mathrm{g} / \mathrm{mL}$ tetracycline.

5. Bacmid selection LB agar plate: 10 g tryptone, 5 g yeast extract, $10 \mathrm{~g}$ agar powder, $10 \mathrm{~g} \mathrm{NaCl}$, and $1 \mathrm{~L}$ ultrapure water. Sterilization at high-pressure steam. $50 \mu \mathrm{g} / \mathrm{mL}$ kanamycin, $7 \mu \mathrm{g} / \mathrm{mL}$ gentamicin, $10 \mu \mathrm{g} / \mathrm{mL}$ tetracycline, $100 \mu \mathrm{g} / \mathrm{mL}$ x-gal, $40 \mu \mathrm{g} /$ mL IPTG Mix and pout into sterile plates (see Note 1 ).

6. TIANprep Mini Plasmid Kit (TIANGEN); Buffers P1, P2, and P3 (see Note 2).

7. Isopropanol.

8. $70 \%$ Ethanol.

9. Sf9 cell line.

10. Sf-900 II Serum-Free Medium.

11. Cellfectin II Reagent (store at $4^{\circ} \mathrm{C}$ ).

12. Cell Culture Dish.

1. $10 \times$ HBS buffer: $100 \mathrm{mM}$ HEPES, $1500 \mathrm{mM} \mathrm{NaCl}$, water (adjust $\mathrm{pH}$ to 7.2 with $\mathrm{NaOH})($ see Note 3 ). 
2. $1 \times$ HBS buffer: $100 \mathrm{~mL} 100 \times$ HBS buffer, $900 \mathrm{~mL}$ water $($ see Note 3).

3. Wash buffer: $10 \mathrm{mM}$ HEPES, pH 7.2, $150 \mathrm{mM} \mathrm{NaCl}, 20 \mathrm{mM}$ imidazole (see Note 4).

4. Elution buffer: $10 \mathrm{mM}$ HEPES, $\mathrm{pH} 7.2,150 \mathrm{mM} \mathrm{NaCl}$, $500 \mathrm{mM}$ imidazole.

5. Coomassie brilliant blue G-250 (Solarbio; see Note 5).

6. Ni-NTA Resin (GE Healthcare).

7. Endoglycosidases Fl and F3; store at $4{ }^{\circ} \mathrm{C}$ (see Note 6).

8. Crossflow ultrafiltration system.

9. Vivaspin Turbo ultrafiltration spin column: membrane 30,000 MWCO PES.

\subsection{Crystallization}

1. Crystallization kits: Crystal Screen, Index, PEG/Ion, PEGRx, SaltRx, Natrix from Hampton Research; Structure Screen, Proplex from Molecular Dimension; Wizard I, Wizard II from Emerald Biosystems; JCSG+Suit from QIANGEN.

2. SWISSCI 3 Lens crystallization plate.

3. Mosquito crystallization setups.

4. 8-Well $5 \mu \mathrm{L}$ micro-reservoir strip.

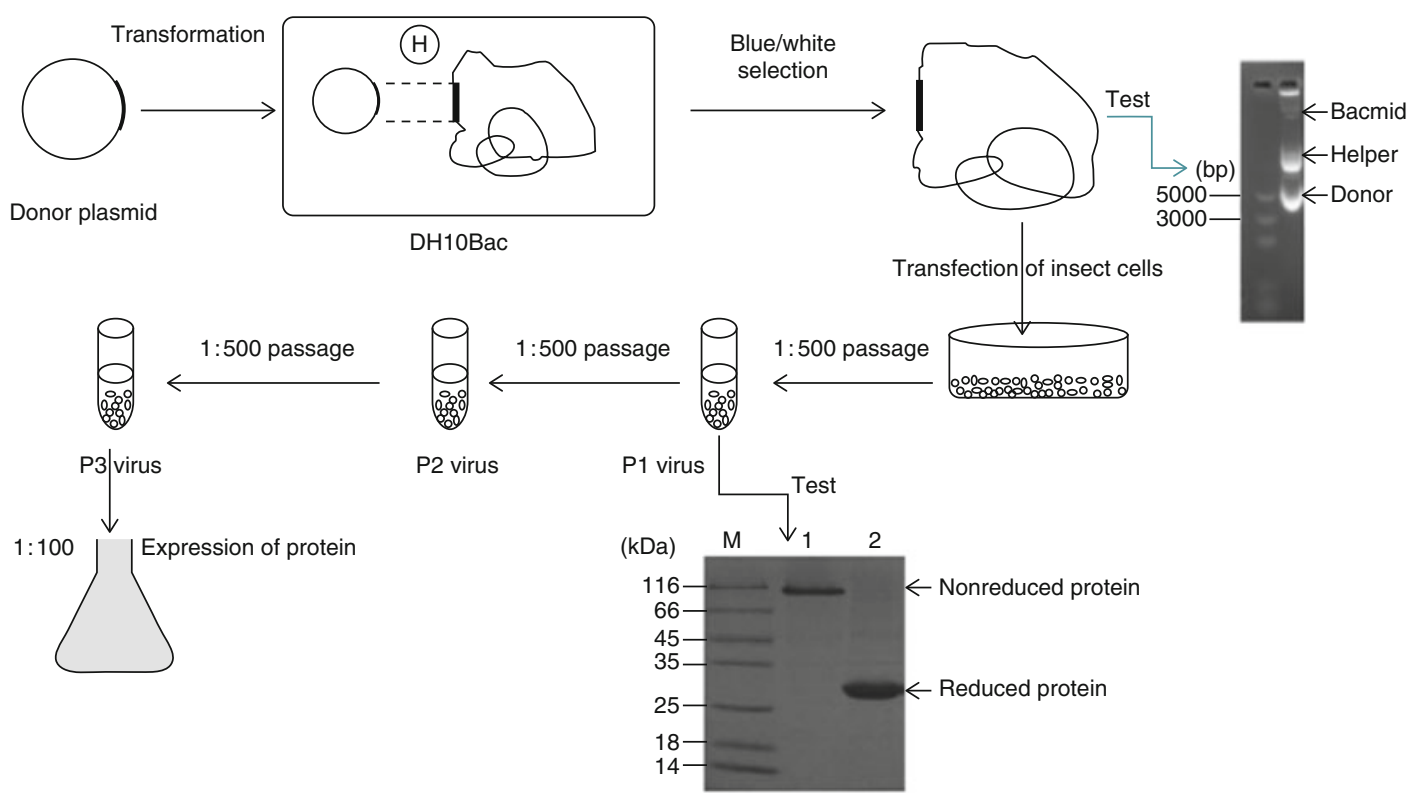

Fig. 1 Schematic diagram of bac-to-bac expression system 
3 Methods

\subsection{Construction of Recombinant \\ Baculovirus}

MER-CoV RBD can be expressed using the Bac-to-Bac baculovirus expression system (Fig. 1), collected and captured using NTA Sepharose (GE Healthcare) and then further purified by gel filtration chromatography using a Superdex 200 High Performance column (GE Healthcare). Crystallization trials are set up using the hanging-drop or sitting-drop vapor diffusion method in conjunction with the sparse-matrix crystal screening kits. The structure of MERS-CoV RBD in complex with MERS-4scFv was determined using the molecular replacement method.

1. Transforming the DHI0Bac cells with the plasmid containing the MERS-CoV RBD gene (see Note 7): add the recombinant plasmid to $50 \mu \mathrm{L}$ of the $\mathrm{DH} 10 \mathrm{Bac}$ competent cells. Incubate on ice for $30 \mathrm{~min}$. Heat-shock the cells for $45 \mathrm{~s}$ at $42{ }^{\circ} \mathrm{C}$ without shaking. Immediately transfer the tubes onto ice and chill for $2 \mathrm{~min}$. Add $500 \mu \mathrm{L}$ of room temperature $\mathrm{LB}$ medium. Shake the tubes at $37^{\circ} \mathrm{C}$ in incubator shaker for $4 \mathrm{~h}$ and then plate $20 \mu \mathrm{L}$ of the cell suspension onto a bacmid selection LB agar plate. Incubate plates for $24-48$ h at $37^{\circ} \mathrm{C}$, dark.

2. Isolation of recombinant bacmid DNA: Pick a white colony from the bacmid selection $\mathrm{LB}$ agar plate, and inoculate $3 \mathrm{~mL}$ of liquid LB selection medium with the picked colony. Harvest the cells by centrifuging at $3000 \times g$ for $10 \mathrm{~min}$, and then remove the entire medium. Add $250 \mu \mathrm{L}$ of buffer Pl containing RNase A to the pellet, and resuspend the cells until the suspension is homogeneous. Transfer the cell suspension to a centrifuge tube. Add $250 \mu \mathrm{L}$ buffer P2 and mix gently by inverting the capped tube several times. Incubate at room temperature for $5 \mathrm{~min}$. Add $350 \mu \mathrm{L}$ Buffer P3 and mix immediately by inverting the capped tube until the mixture is homogeneous. Centrifuge the mixture at $15,000 \times g$ at room temperature for $10 \mathrm{~min}$. Transfer $800 \mu \mathrm{L}$ of the supernatant into a $2 \mathrm{~mL}$ tube with $500 \mu \mathrm{L}$ pre-chilled isopropanol at $-20{ }^{\circ} \mathrm{C}$ for $20 \mathrm{~min}$. Centrifuge the mixture at $15,000 \times g$ at $4{ }^{\circ} \mathrm{C}$ for $20 \mathrm{~min}$. Carefully discard the supernatant. Resuspend the DNA pellet in $1 \mathrm{~mL}$ of $70 \%$ ethanol. Centrifuge at $15,000 \times g$ at $4{ }^{\circ} \mathrm{C}$ for $5 \mathrm{~min}$. Carefully discard the supernatant. Air-dry the pellet for $30 \mathrm{~min}$. Resuspend the DNA pellet in $50 \mu \mathrm{L}$ of sterile ultrapure water (see Note 8 ).

3. Confirm the bacmid quality by separating the DNA on a $0.5 \%$ agarose gel. The bacmid is in the position nearest the gel hole. Verify the presence of the MERS-CoV RBD gene in the recombinant bacmid by PCR, using Ml3 forward and reverse primers 
(M13 F: CCCAGTCACGACGTTGTAAAACG; M13 R: AGCGGATAACAATTTCACACAGG; optional).

4. Transfection of Sf9 cells: verify that the $S f 9$ cells are in the $\log$ phase $\left(1.5-2.5 \times 10^{6}\right.$ cells $\left./ \mathrm{mL}\right)$ with greater than $95 \%$ viability. Add $2 \times 10^{6}$ cells into a $10 \mathrm{~cm}$ dish with $2 \mathrm{~mL}$ of culture medium (Sf-900 II Serum Free). Allow the cells to attach themselves for 30-60 $\mathrm{min}$ at room temperature in the hood. For the transfection sample, dilute $10 \mu \mathrm{L}$ Cellfectin II Reagent in $250 \mu \mathrm{L}$ of culture medium (Sf-900 II Serum Free). Mix by inverting 5-10 times (do not vortex), and incubate for $5 \mathrm{~min}$ at room temperature. Add $1 \mu \mathrm{g}$ of bacmid DNA. Mix by inverting 5-10 times (do not vortex), and incubate for $20 \mathrm{~min}$ at room temperature. Add the entire DNA-lipid mixture dropwise onto the cells. Incubate the cells at $27^{\circ} \mathrm{C}$ for $5 \mathrm{~h}$ and then remove the supernatant and add $7 \mathrm{~mL}$ of fresh culture medium (Sf-900 II Serum Free).

5. After 7-9 days or until visible signs of virus infection (see Note 9), transfer the medium containing the virus to sterile $15-\mathrm{mL}$ tubes. Centrifuge the tube at $600 \times \mathrm{g}$ for $5 \mathrm{~min}$ to remove cells and large debris. Transfer this clarified supernatant to a fresh $15-\mathrm{mL}$ tube.

6. Store this $\mathrm{P} 0$ virus stock at $4{ }^{\circ} \mathrm{C}$, protected from light (see Note 10).

7. Amplifying the baculovirus stock: On the day of infection, prepare an Sf9 cell suspension by seeding at $2 \times 10^{6}$ cells $/ \mathrm{mL}$ in $50 \mathrm{~mL}$ of culture medium. Add $100 \mu \mathrm{L}$ of P0 virus stock to the flask. Incubate the suspended cells for $72-96$ h at $27^{\circ} \mathrm{C}$ in incubator shaker. Transfer the medium containing the virions from the flask to a sterile $50-\mathrm{mL}$ tube, and centrifuge the tube at $600 \times g$ for $5 \mathrm{~min}$ to clarify the baculovirus stock. Transfer the supernatant to a fresh collection tube. This is the $\mathrm{Pl}$ virus stock.

8. Store this $\mathrm{Pl}$ virus stock at $4{ }^{\circ} \mathrm{C}$, protected from light. The P2 and P3 virus can be obtained by repeating step 7 .

3.2 Protein

Expression and Purification
1. The high-titer P2 baculovirus stock was used to infect $2 \times 10^{6}$ Sf9 cells per milliliter. The baculovirus virions are generally added according to the virus to cell volume ratio of $1: 100$ and then the Sf9 cells are cultured at $27^{\circ} \mathrm{C}$ in incubator shaker for $48-60 \mathrm{~h}$.

2. After transfection for 48-60 h, collect the cell-culture supernatant containing the MERS-CoV RBD by centrifugation at $3000 \times g$ for $15 \mathrm{~min}$ to remove cells, and pass the supernatant through a $0.45 \mu \mathrm{m}$ filter, to avoid blocking the filter of the crossflow ultrafiltration system. 
3. For subsequent purification, concentrate large volumes of supernatant to a smaller volume. We used the Sartorius crossflow ultrafiltration system for concentration. When the volume is concentrated to about $50 \mathrm{~mL}$, add $200 \mathrm{~mL}$ portions of HBS buffer ( $1 \mathrm{~L}$ in total) to the big beaker to exchange the buffer. When the total volume remaining is reduced to $50 \mathrm{~mL}$, add $100 \mathrm{~mL}$ HBS buffer to collect all the liquid in the system in a beaker. Then dispense into high-speed centrifuge tubes, centrifuge at $3000 \times g$ for $1 \mathrm{~h}$ at $4{ }^{\circ} \mathrm{C}$.

4. The supernatant after centrifugation is loaded onto the nickelNTA beads equilibrated with $30 \mathrm{~mL}$ of HBS buffer. MERS$\mathrm{CoV}$ RBD with a His tag could be captured by nickel-NTA beads. Repeat loading the sample once more.

5. Add wash buffer to the beads to remove the nonspecifically bound proteins until the flow-through is not able to discolor the Coomassie Brilliant Blue G250 solution.

6. After adding elution buffer, the target protein will dissociate from the beads; collect it in a $10 \mathrm{kDa}$ Millipore concentrating tube. Similarly, detect protein with Coomassie Brilliant Blue G250. The concentrating tube containing the protein sample is centrifuged at $3000 \times g$ to concentrate the sample to less than

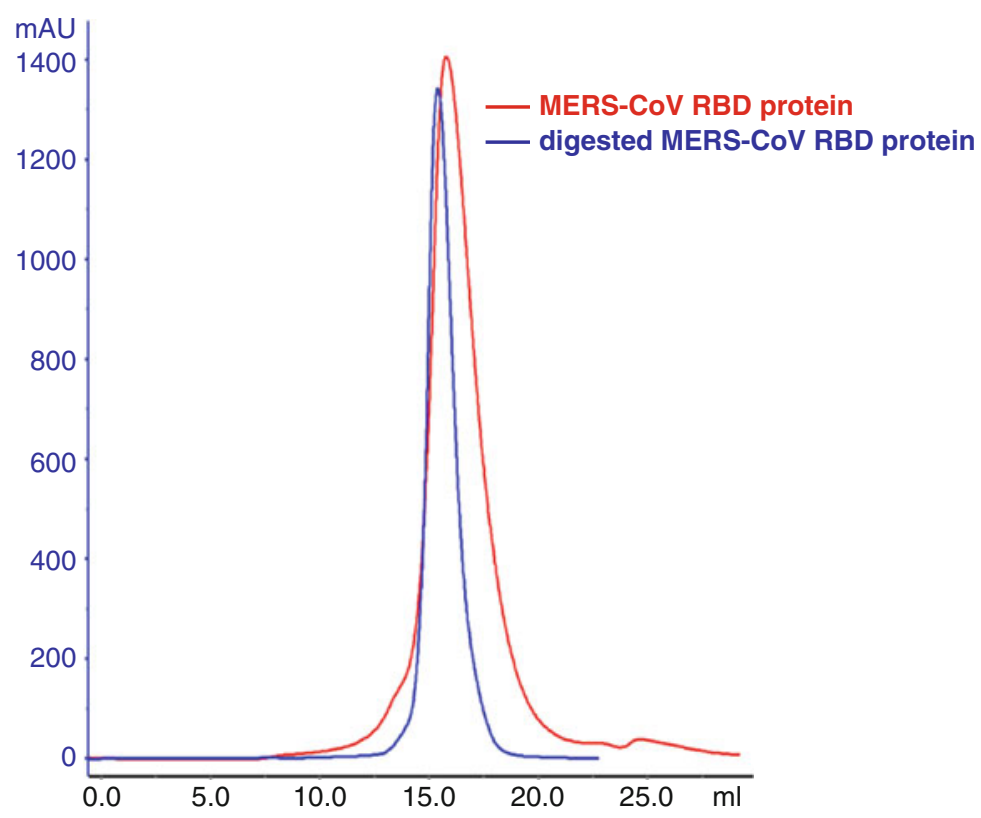

Fig. 2 Gel filtration profile of MERS-COV RBD protein and digested by endoglycosidase F1 and F3 MERS-CoV RBD protein, confirmed by SDS-PAGE. The first two lanes are MERS-CoV RBD protein and the last two lanes are digested RBD protein 
$1 \mathrm{~mL}$. Transfer the sample to a $1.5 \mathrm{~mL}$ EP tube and centrifuge at $3000 \times g$ for $10 \mathrm{~min}$.

7. MERS-CoVRBD is further purified by gel filtration chromatography. The sample is loaded onto the Superdex 200 column pre-equilibrated with HBS buffer. Fractions containing RBD are collected and the protein's purity is confirmed by SDS-PAGE (Fig. 2).

8. Dilute the protein to $1 \mathrm{mg} / \mathrm{mL}$, and digest with endoglycosidase $\mathrm{Fl}$ and $\mathrm{F} 3(\mathrm{Fl} / \mathrm{F} 3$ : RBD at the ratio of $1: 100)$ at $18{ }^{\circ} \mathrm{C}$ overnight. The digested protein is concentrated and purified by gel filtration chromatography same as above (optional).

9. After preparing the MERS-CoV RBD protein and MERS$4 \mathrm{scFv}$ protein (see Note 11 ) detect the absorption of the protein sample at $280 \mathrm{~nm}$ (A280). According to the molecular weight and extinction coefficient, the molar concentration can be calculated. The two proteins were mixed at molar ratio of $\mathrm{l}: \mathrm{l}$, incubated on ice for $\mathrm{l} \mathrm{h}$, and purified using a Superdex 200 column. Collect the fractions containing the complex and confirm the protein purity by SDS-PAGE.

\subsection{Crystallization}

1. Collect the purified MERS-CoV RBD protein and use a $2 \mathrm{~mL}$ Sartorius centrifugal concentrator to concentrate to $10-15 \mathrm{mg} / \mathrm{mL}$. After mixing and aspirating, centrifuge at $10,000 \times g$ for $10 \mathrm{~min}$ at $4{ }^{\circ} \mathrm{C}$.

2. Use commercial reservoir solution kits for crystallization. Every kit has at least 96 different conditions, including salt, buffer, precipitant, and $\mathrm{pH}$. Dispense $30 \mu \mathrm{L}$ reservoir solution onto the 96-well SWISSCI3 Lens crystallization plate.

3. Use TTP LabTech's mosquito crystallization setup for automated crystallography. Absorb $3 \mu \mathrm{L}$ protein on the 8 -well $5 \mu \mathrm{L}$ micro-reservoir strip (Fig. 3a). Then the needles aspirate the protein from the strip onto the SWISSCI plate with $200 \mathrm{~nL}$ of protein per well (Fig. 3b), using the sitting-drop vapor diffusion method by mixing $200 \mathrm{~nL}$ reservoir and $200 \mathrm{~nL}$ reservoir (Fig. 3c,d).

4. Seal the plate with tape and gently place it in an $18^{\circ} \mathrm{C}$ room.

5 . Check the sample drops under a microscope at 20-100× magnifications after 3 and 7 days (and if necessary, after 1 and 2 weeks, and 1,3 , and 6 months).

6. A week later, we found crystal growth in the PEG/Ion, PEGRX and JCSG+ kits. Specific conditions were as follows (Fig. 4a,b). PEG/ION:0.2 M Potassium sodium tartrate tetrahydrate, $20 \% \mathrm{w} / \mathrm{v}$ polyethylene glycol 3350.PEGRx:0.1 M BICINE $\mathrm{pH} 8.5,20 \% \mathrm{w} / \mathrm{v}$ polyethylene glycol 10,000. JCSG +: $0.2 \mathrm{M}$ Potassium nitrate, 20\%(w/v) PEG 3350. 
A

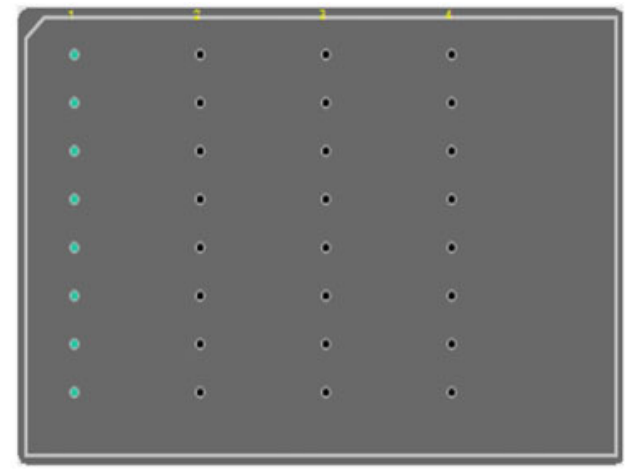

C

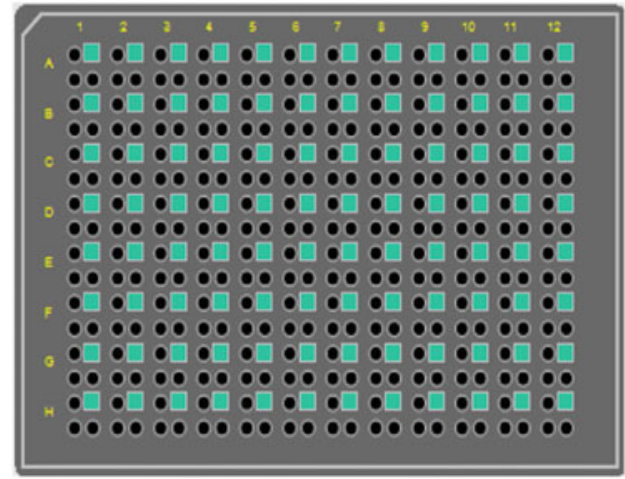

E

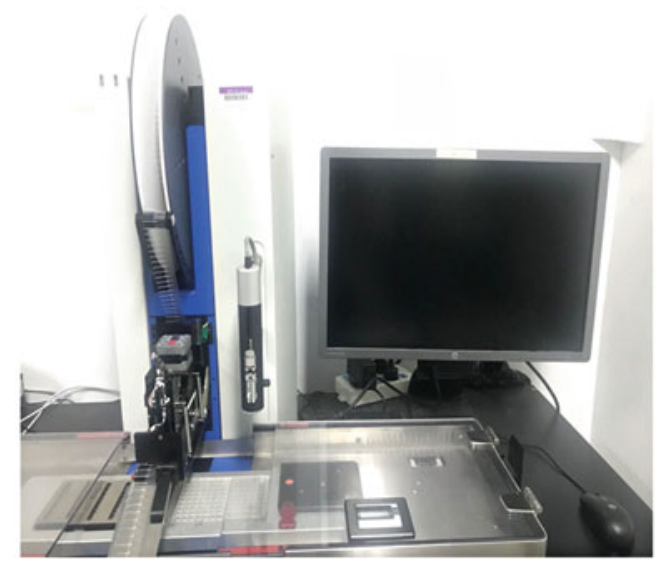

B

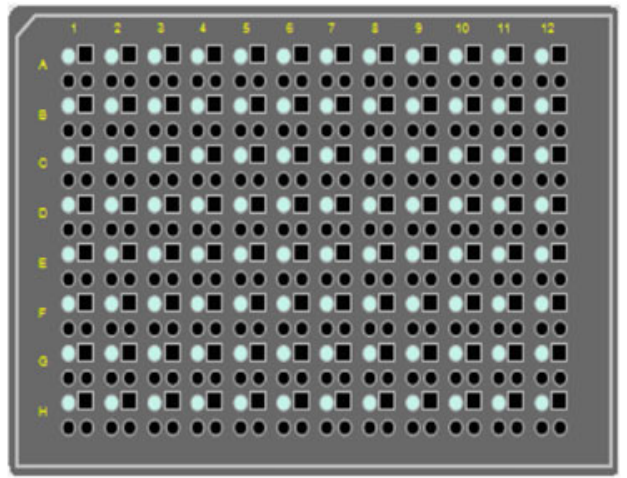

D

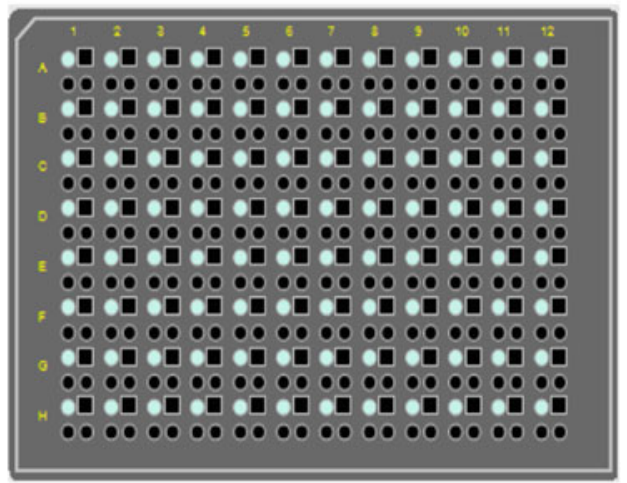

$\mathbf{F}$

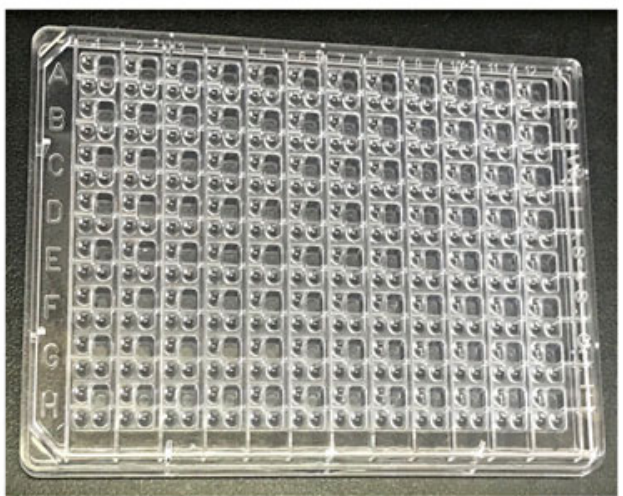

Fig. 3 Crystallization by mosquito. Panel a-d shows the operation diagram of the TTP LabTech's setups: blue dots represent proteins, and square lattices represent reservoir. Panel e shows the TTP LabTech's Mosquito machine. Panel $\mathbf{f}$ shows the SWISSCI plate

\subsection{Structural Determination}

1. All crystals should be flash-frozen in liquid nitrogen after being incubated in the reservoir solution containing $20 \%(\mathrm{v} / \mathrm{v})$ glycerol. 
A

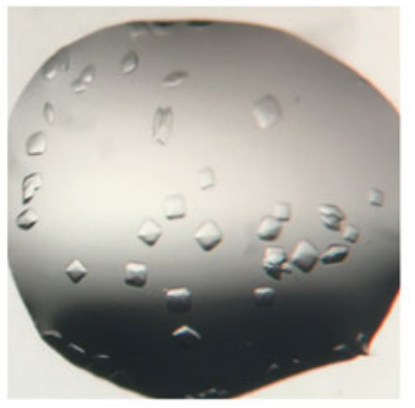

B

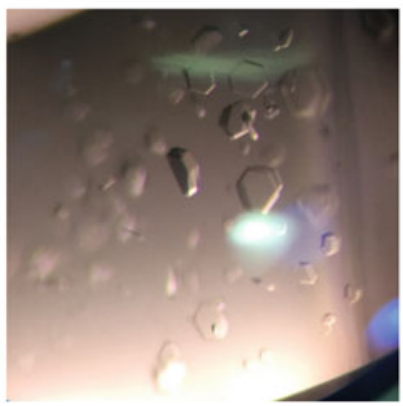

C

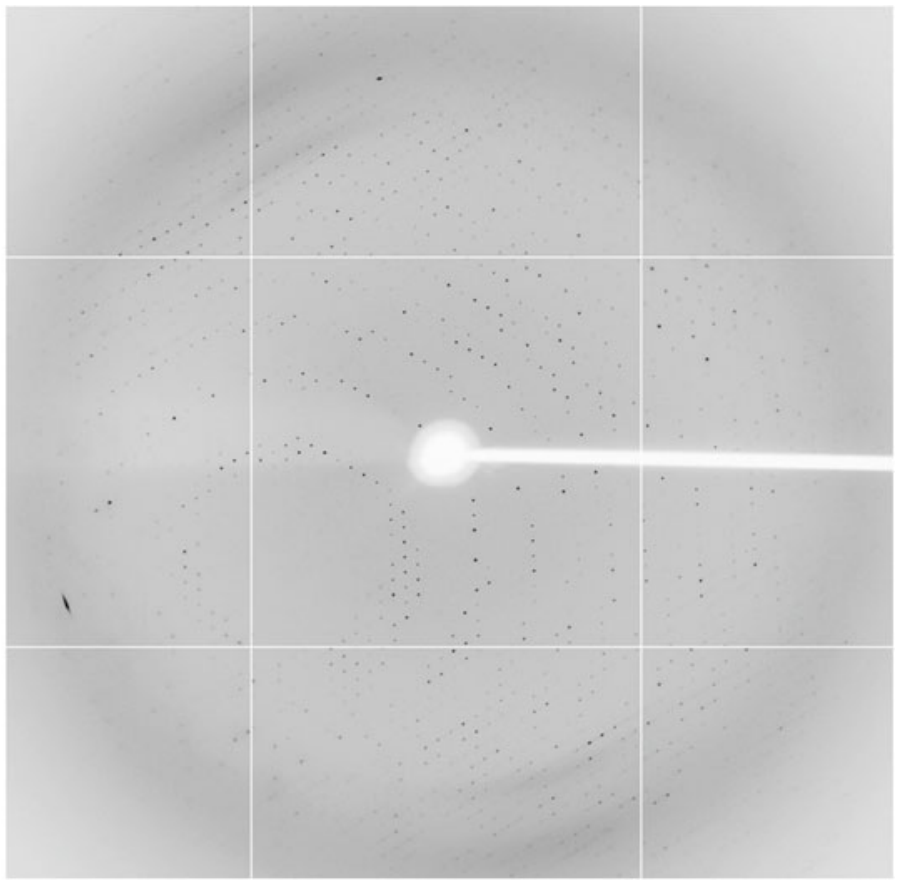

Fig. 4 Crystals of MERS-CoV RBD and MERS-4scFv complex (a, b) and the X-ray diffraction pattern of the crystal complex (c)

2. The diffraction images should be collected on the BLI7U beamline (Fig. 4c). Rotate the mounted crystal and the X-ray diffraction patterns should be recorded at $1^{\circ}$ per image, and collected for $360^{\circ}$.

3. The diffraction images in a dataset should be processed with HKL2000 [10] including auto-index, refinement, integration, and scaling steps. After data processing, the crystal unit cell parameters, crystal space group, Miller indexes of reflections, intensities, and error estimates of reflections should be determined and stored in a *.sca file, which provides the dataset applicable to structure determination.

4. Using CCP4 suite solve the structure as follows: Export the $*$. sca file to a $*$.mtz file using the program SCALPACK2MTZ. Use the $*$.mtz file to calculate the solvent via MATTHEWS_COEF. Run with PHASER MR (see Note 12) with the MERSCoV RBD structure (PDB ID: 4172) and the structures of the variable domain of the heavy and light chains available in the PDB with the highest sequence identities as search models (see Note 12) [11]. When the phases are determined, the electron density map can be calculated, from which the molecular model can be constructed. 
5. Subsequent model building and refinement were performed using COOT and PHENIX, respectively (see Note 13) $[12,13]$.

6. Many validation programs are used to check the structure, until the investigator is satisfied, and then the structure can be deposited in the PDB.

\section{Notes}

1. Weigh $10 \mathrm{~g}$ tryptone, $5 \mathrm{~g}$ yeast extract, $10 \mathrm{~g}$ agar powder, and $10 \mathrm{~g} \mathrm{NaCl}$, and add ultrapure water to $1 \mathrm{~L}$. After sterilization by high-pressure steam, wait until the temperature of the medium drops to about $60{ }^{\circ} \mathrm{C}$, add the required antibiotics, inducers etc. $(50 \mu \mathrm{g} / \mathrm{mL}$ kanamycin, $7 \mu \mathrm{g} / \mathrm{mL}$ gentamicin, $10 \mu \mathrm{g} / \mathrm{mL}$ tetracycline, $100 \mu \mathrm{g} / \mathrm{mL}$ - gal, $40 \mu \mathrm{g} / \mathrm{mL}$ IPTG). Mix evenly and then pour into sterile plates. When the culture medium has cooled and solidified, store the bacmid selection LB agar plate at $4{ }^{\circ} \mathrm{C}$.

2. TIANprep Mini Plasmid Kit includes Buffers P1, P2, and P3. We only use the Buffers P1, P2, and P3 for the preceding steps of isolating recombinant bacmid DNA.

3. Method for preparing HBS buffer: Prepare $10 \times$ HBS buffer (100 mM HEPES, $1500 \mathrm{mM} \mathrm{NaCl}$ ). Weigh 23.8 g HEPES (Sigma), $87.66 \mathrm{~g} \mathrm{NaCl}$ (Amresco) dissolve with water to $1 \mathrm{~L}$, adjust $\mathrm{pH}$ to 7.2 with $\mathrm{NaOH}$. Then, dilute $100 \mathrm{~mL}$ of $10 \times$ HBS buffer with $900 \mathrm{~mL}$ of water.

4. Method of preparing wash buffer: First prepare $5 \mathrm{M}$ imidazole. Weigh 340 g imidazole (Sigma-Aldrich, USA), add water to $1 \mathrm{~L}$ and use $\mathrm{HCl}$ to adjust $\mathrm{pH}$ to 8.0 . Add $100 \mathrm{~mL} 10 \times \mathrm{HBS}$ buffer, $30 \mathrm{~mL} 5 \mathrm{M}$ imidazole with water to $1 \mathrm{~L}$.

5. Method of preparing Coomassie brilliant blue G-250: Weigh $1 \mathrm{~g} \mathrm{G}-250$ (Solarbio), add $100 \mathrm{~mL} \mathrm{85 \%} \mathrm{phosphate,} 100 \mathrm{~mL}$ anhydrous ethanol and water to $1 \mathrm{~L}$. The G-250 needs to be stored away from light.

6. Endoglycosidase F1 and F3 are expressed and purified from E. coli by our laboratory. The endoglycosidase was added into the reaction system according to the mass ratio of $1: 100$.

7. The coding sequence of the MERS-CoV RBD (EMC strain, spike residues 367-588) was ligated into the pFastBac-Dual vector (Invitrogen) with a $\mathrm{N}$-terminal gp67 signal peptide to enable the protein secreting outside the cell and a C-terminal His-tag to facilitate further purification processes.

8. Allow the pellet to dissolve for at least $10 \mathrm{~min}$ at room temperature. To avoid shearing the DNA, pipet only 1-2 times to 
resuspend. Store the bacmid at $4{ }^{\circ} \mathrm{C}$ and use it as soon as possible, usually within 1 week. Aliquot the bacmid DNA into separate tubes and store at $-20{ }^{\circ} \mathrm{C}$ (not in a frost-free fridge). Avoid multiple freeze/thaw cycles as this decreases the transfection efficiency.

9. Characteristics of infected cells: A $25-50 \%$ increase in cell diameter can be seen and the size of cell nuclei increases at the early stage. Cells release from the plate and appear lysed, showing signs of clearing in the monolayer.

10. P0 virus can be stored for years, adding $2 \%(\mathrm{v} / \mathrm{v}) \mathrm{FBS}$ at $4{ }^{\circ} \mathrm{C}$, protected from light.

11. The expression of MERS-4scFv protein was conducted in $293 \mathrm{~F}$ cells transiently transfected with plasmid DNA. After $72 \mathrm{~h}$, the supernatant was collected and concentrated. The purified MERS-4scFv protein was obtained by Ni-NTA affinity chromatography and Superdex 200 size-exclusion chromatography. The purification method is the same as that of RBD protein.

12. If the crystal structure of the same protein or a similar protein has been solved, the molecular replacement method can be applied. After obtaining the solutions of the rotation and translation functions, initial phases can be calculated from the reference model, after which the electron density can be calculated.

13. The accuracy of the constructed model is confirmed by the crystallographic R-factor and R-free, which indicate the discrepancy between the calculated and observed amplitudes. The stereo-chemical parameters of the model can also be checked using programs such as MOLPROBITY, PROCHECK, or RAMPAGE.

\section{Acknowledgment}

This work was supported by the National Key Plan for Scientific Research and Development of China (Grant No. 2016YFD0500307).

\section{References}

1. Lu G et al (2013) Molecular basis of binding between novel human coronavirus MERS-CoV and its receptor CD26. Nature 500 (7461):227-231

2. Yu X et al (2015) Structural basis for the neutralization of MERS-CoV by a human monoclonal antibody MERS-27. Sci Rep 5:13133
3. Zhang S et al (2018) Structural definition of a unique neutralization epitope on the receptorbinding domain of MERS-CoV spike glycoprotein. Cell Rep 24(2):441-452

4. Niu P et al (2018) Ultrapotent human neutralizing antibody repertoires against Middle East respiratory syndrome coronavirus from a recovered patient. J Infect Dis 218 (8):1249-1260 
5. Wang L et al (2015) Evaluation of candidate vaccine approaches for MERS-CoV. Nat Commun 6:7712

6. Ying $\mathrm{T}$ et al (2015) Junctional and allelespecific residues are critical for MERS-CoV neutralization by an exceptionally potent germline-like antibody. Nat Commun 6:8223

7. Du L et al (2016) Introduction of neutralizing immunogenicity index to the rational design of MERS coronavirus subunit vaccines. Nat Commun 7:13473

8. Wang L et al (2018) Importance of neutralizing monoclonal antibodies targeting multiple antigenic sites on MERS-CoV spike to avoid neutralization escape. J Virol 92(10). https:// doi.org/10.1128/JVI.02002-17
9. Wang N et al (2013) Structure of MERS-CoV spike receptor-binding domain complexed with human receptor DPP4. Cell Res 23 (8):986-993

10. Otwinowski Z, Minor W (1997) Processing of $\mathrm{X}$-ray diffraction data collected in oscillation mode. Methods Enzymol 276:307-326

11. McCoy AJ et al (2007) Phaser crystallographic software. J Appl Crystallogr 40(Pt 4):658-674

12. Emsley P, Cowtan K (2004) Coot: modelbuilding tools for molecular graphics. Acta Crystallogr D Biol Crystallogr 60(Pt $12 \mathrm{Pt}$ 1):2126-2132

13. Adams PD et al (2002) PHENIX: building new software for automated crystallographic structure determination. Acta Crystallogr D Biol Crystallogr 58(Pt 11):1948-1954 